MT-DP - 2016/11

\title{
How Brexit affects European Union power distribution
}

LÁSZLÓ Á. KÓCZY 


\title{
Discussion papers
}

MT-DP - 2016/11

Institute of Economics, Centre for Economic and Regional Studies, Hungarian Academy of Sciences

KTI/IE Discussion Papers are circulated to promote discussion and provoque comments. Any references to discussion papers should clearly state that the paper is preliminary. Materials published in this series may subject to further publication.

How Brexit affects European Union power distribution

\author{
Author: \\ László Á. Kóczy \\ senior research fellow \\ Institute of Economics, Centre for Economic and Regional Studies, \\ Hungarian Academy of Sciences \\ and Keleti Faculty of Business and Management \\ Óbuda University \\ e-mail: koczy@krtk.mta.hu
}

May 2016

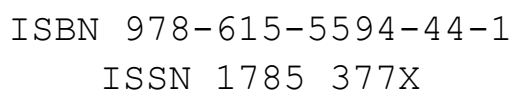




\title{
How Brexit affects European Union power distribution
}

\author{
László Á. Kóczy
}

Abstract

The possible exit of the United Kingdom from the European Union will have profound economic and political effects. Here we look at a particular aspect, the power distribution in the Council of the European Union. Since the Lisbon treaty the exit does not require new negotiations as the success of a voting initiative only depends on the number and total population of the supporting member states. Using the Shapley-Shubik power index we calculate the member states' powers with and without the United Kingdom and update earlier power forecasts using the Eurostat's latest population projections. There is a remarkably sharp relation between population size and the change in power: Brexit increases the largest members', while decreases the smallest ones' powers.

JEL: C71, D72

Keywords: European Union, Council of the European Union, qualified majority voting, power index, a priori voting power, demographics

\section{Acknowledgement}

The author thanks the Hungarian Academy of Sciences for the financial support (LP-004/2010) and the National Research, Development and Innovation Office for the grant K-109354. 


\title{
Hogyan hat a Brexit az Európai Unió hatalmi viszonyaira?
}

\author{
Kóczy Á. László
}

Összefoglaló

Az Egyesült Királyságnak az Európai Unióból való kilépésének jelentős hatása lesz a gazdaságra és a politikára. A tanulmányban egy konkrét szempontot vizsgálunk, az Európai Unió Tanácsának hatalmi viszonyait. A Lisszaboni Szerződés óta a kilépés nem igényel új tárgyalásokat: egy szavazási javaslat sikere csak a támogatók számától és össznépességétől függ. A Shapley-Shubik-index segítségével meghatározzuk a tagállamok hatalmi befolyását az Egyesült Királysággal és nélküle és az Eurostat legújabb népesség előrejelzései alapján frissítjük a hatalmi várakozásokat. Meglepően erôs kapcsolat mutatkozik a népesség nagysága és a hatalmi változás között: A Brexit növeli a legnagyobb országok befolyását, míg a legkisebbekét csökkenti.

\section{JEL: C71, D72}

Tárgyszavak: Európai Unió, az Európai Unió Tanácsa, minősített többségi szavazás, hatalmi index, a priori szavazási hatalom, demográfia 


\title{
How Brexit affects European Union power distribution*
}

\author{
László Á. Kóczy ${ }^{\dagger}$
}

\begin{abstract}
The possible exit of the United Kingdom from the European Union will have profound economic and political effects. Here we look at a particular aspect, the power distribution in the Council of the European Union. Since the Lisbon treaty the exit does not require new negotiations as the success of a voting initiative only depends on the number and total population of the supporting member states. Using the Shapley-Shubik power index we calculate the member states' powers with and without the United Kingdom and update earlier power forecasts using the Eurostat's latest population projections. There is a remarkably sharp relation between population size and the change in power: Brexit increases the largest members', while decreases the smallest ones' powers.
\end{abstract}

JEL codes: C71, D72

*The author thanks the Hungarian Academy of Sciences for the financial support (LP004/2010) and the National Research, Development and Innovation Office for the grant K-109354.

${ }^{\dagger}$ Centre for Economic and Regional Studies, Hungarian Academy of Sciences, Budaörsi út 45., H-1112 Budapest, Hungary and Keleti Faculty of Business and Management, Óbuda University, TavaszmezÅŚ utca 15-17. H-1084 Budapest. Email: koczy@krtk.mta.hu 
Keywords and phrases: European Union, Council of the European Union, qualified majority voting, power index, a priori voting power, demographics.

\section{Introduction}

Britain's relation to the European Union has never been simple. Britain was initially not interested in joining the European Economic Community. When it changed its mind its membership request was vetoed by France - twice. It finally joined only in 1973, but even since the relation has been complicated. The Brexit - the withdrawal of the United Kingdom from the European Union has been on the agenda ever since it joined in 1973. In 2013, however, David Cameron Conservative prime minister committed to hold a referendum after his reelection: The referendum is scheduled for 23 June 2016. Britain would not be the first departure from the European Union, since Greenland has left in 1985 over disagreements in fishing rights, but it would be the first sovereign country and its departure would have widespread effects on life and economy both in the UK and in Europe (Buckle et al., 2015; Dagnis Jensen and Snaith, 2016; Oliver, 2016). Our goal is not to provide a comprehensive review of such likely effects: we look at the consequences of the Brexit on the voting in the European Council, better known by its former name, the Council of Ministers.

The European Council is one of the main decision making bodies of the European Union. Unlike in the European Parliament, for instance, each country is represented by a single individual; the size differences between countries are expressed by weighted qualified majority voting. Since the treaty of Lisbon voting is successful if at least $55 \%$ of the countries, having 
at least $65 \%$ of the population vote in favour. Previously each country had, additionally, an artificial weight and this weight played the primary role in determining voting power. Back in those days each extension of the European Union created long debates on the new weights; the new voting rules made the accession of Croatia smoother, but also enables us to have clear predictions on what will happen should the United Kingdom choose departure.

This short note then has two parts. After introducing the power index method firstly we update the power predictions using the more recent data from Eurostat and then recalculate these with a 27 member EU in mind.

\section{Preliminaries}

Voting situations can be modelled by simple games: cooperative games with transferable utility where winning coalitions get a payoff 1 , losing coalitions get 0 . We are interested in power, that is, the ability to change decisions. In this paper we are particulary interested in power indices that show the individual voters' share of decisions. Such indices show that if a decision is made, what is the probability that a particular player was instrumental in making this decision. Translate this into politics and voting about the spending of a budget and the index shows the probability that the spending of a euro (or a billion) was according to the interests of this particular player. While the model is clearly a simplification, a power index shows the percentual shares of a given budget that the individual voters spend according to their interests.

The Shapley-Shubik index $\phi$ (Shapley and Shubik, 1954) is one of the best known power indices that applies the Shapley value (Shapley, 1953) to simple games: Voters arrive in a random order; if and when a coalition turns winning the full credit is given to the last arriving, the pivotal player. A 
player's power is given as the proportion of orderings where it is pivotal, formally for any simple voting game $v$ player $i$ 's Shapley-Shubik index in game $v$ is as follows

$$
\phi_{i}(v)=\sum_{S \subseteq N \backslash\{i\}} \frac{s !(n-s-1) !}{n !} v_{i}^{\prime}(S),
$$

where $s=|S|$.

There are many alternatives to the Shapley-Shubik index; the PenroseBanzhaf measure and index is the most commonly used one, but recently the nucleolus has also been considered for measuring power; in fact Zaporozhets et al. (2016) find that if power and needs both determine the allocation of a budget, the nucleolus (Schmeidler, 1969; Montero, 2013) - though very difficult to compute - is, theoretically a better alternative.

\section{Data and results}

Voting in the European Council solely depends on population numbers. We have used data from Eurostat (2014) for current populations and for forecasts until 2080. The data are presented in Table 1. We have used IOP - Indices of Power 2.05 (Bräuninger and König, 2005) to calculate the Shapley-Shubik indices of the countries. First for the current 28-member European Union, then for the 27-member European Union without the United Kingdom.

The changes in power are largely predictable. The Property of New Members (Brams and Affuso, 1976; Kóczy, 2009) states that the appropriate extension of a weighted voting game by new players should reduce the voting power of the incumbent members. Conversely, the departure of a voter should lead to higher powers. The departure of the United Kingdom leads to higher power Shapley-Shubik index values - for most players. For the 
smallest member states we observe a Paradox of New Members: they enjoy a higher power together with the United Kingdom than without. The occurrence of this paradox is not uncommon (van Deemen and Rusinowska, 2003; Rusinowska and van Deemen, 2005) and hardly surprising. Small players do not contribute much in terms of population, but can be pivotal in turning a coalition winning if the population is there, but there is a shortage of supporting countries. The departure of one of the largest member states eliminates such opportunities, in a way small countries are complementary to large ones. The largest gains are collected by the largest members, and most countries benefit from the departure.

Do they benefit? What we have seen here is that the conditional probability that if a decision is made, it is a particular player who made the decision is increased for most players. On the other hand we must also be aware of the fact that the United Kingdom, despite many concessions it was able to obtain, remains a net contributor to the budget of the European Union. The Brexit therefore does not only mean that this abstract conditional probability changes, but also that the cake to share becomes smaller. So if we want to translate power to euros, a fair comparison should account for the smaller cake, too. About $8.822 \%$ of the budget of the European Union is paid by the United Kingdom (European Parliament, 2015) and even if we subtract the benefits it gets from various EU programmes, the EU budget and hence the monetary benefits must be scaled down by $96.61 \%$. The adjusted indices are presented in Table 4.

With this adjustment many more countries lose by the Brexit. Countries with a population below 6 million, lose up to $10 \%$ of the original resources, while those up to about 20 million moderately gain. Interestingly the largest 4 members: France, Germany, Italy, and Spain gain much even after dis- 


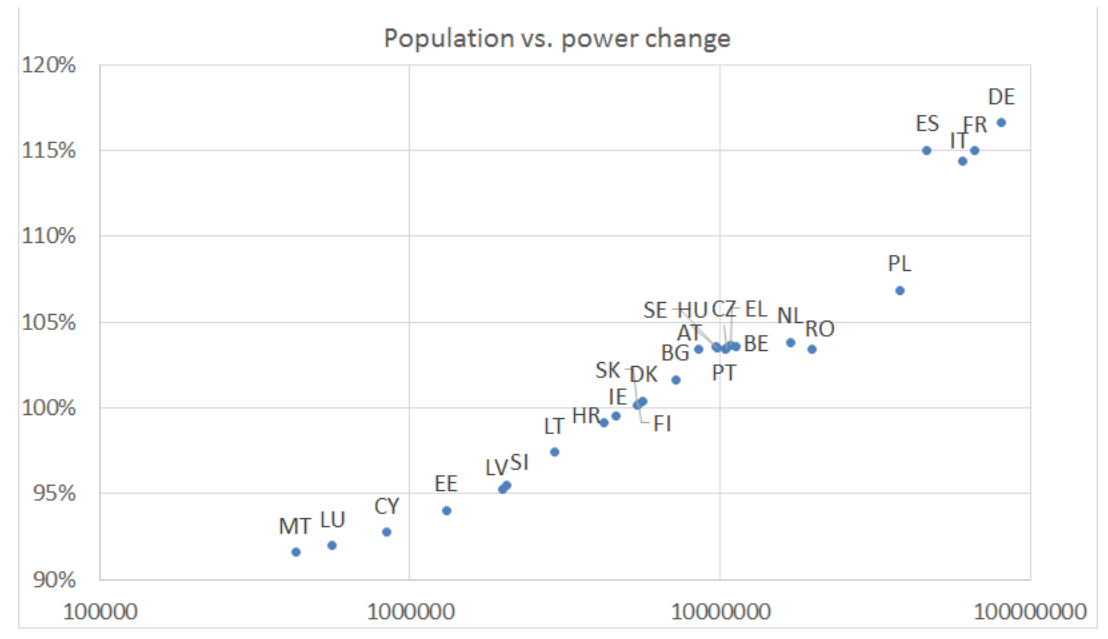

Figure 1: Adjusted power indices as a percentage of the pre-Brexit power indices versus populations in 2015 labelled by EU country codes

counting gains. The biggest winner is clearly Spain gaining over $30 \%$ on the long run. So how do these countries react to the idea of Brexit? Annette Kroll and Leuffen (2016) explain the game that the UK wants to play, by threatening Europe with their exit. While the threat seems credible, it was not able to achieve substantial policy changes. Yet there was a substantial difference between member states that expect to get a stronger or weaker position in the European politics after Brexit. Annette Kroll and Leuffen (2016); Hix et al. (2016) discuss the policy side, here we find that the voting powers change differently, too, adding another aspect to the incentives.

While it is a little difficult to study comparative statics with power indices, it is noticeable that all small countries lose power, sometimes more than $15 \%$, the biggest winners are large countries. Figure 3 shows the (budget-adjusted) change in power indices versus the member state populations. The trend is quite clear, but why? To understand this, we have to look at the way the Shapley-Shubik index is calculated and the rules of the qualified majority voting. The Shapley-Shubik index looks at average marginal contributions, 


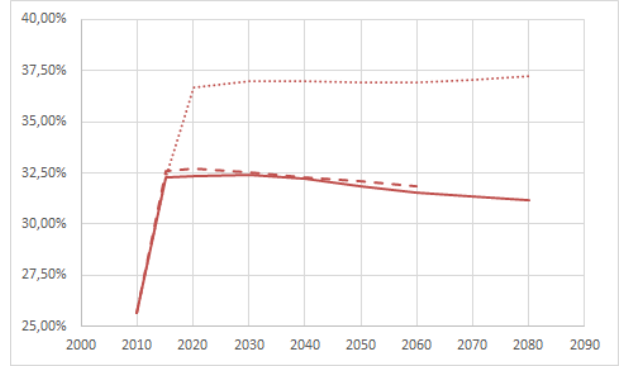

(a) Core countries

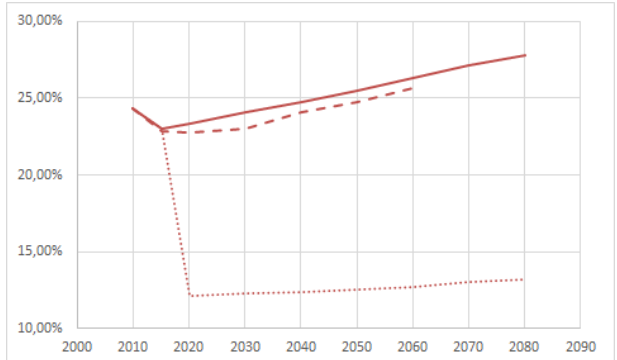

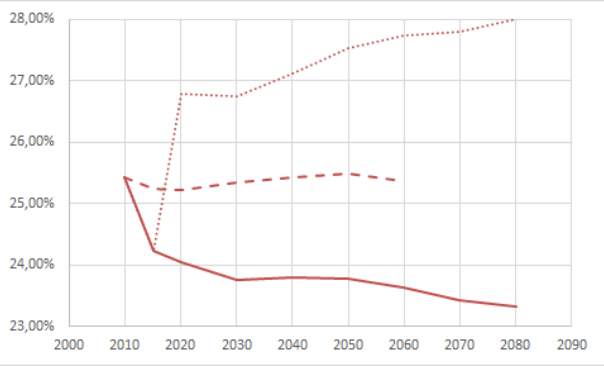

(b) Southern countries

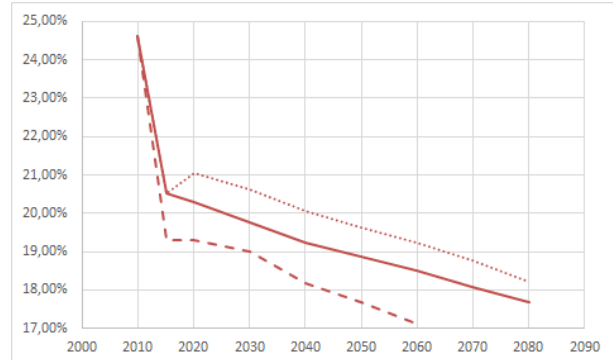

(c) Northern countries, Baltics, and (d) Central Eastern European CounAustria tries

Figure 2: Power index projections for four regions. Dashed / solid / dotted lines respectively show 2010 (Kóczy, 2012), current, and Brexit forecasts 
but in a simple game the contributions are all 0 except when the addition of a player turns a losing coalition into winning. ${ }^{1}$ The voting rule states two conditions for a successful vote: the support of a certain number of countries and a certain percentage of the population. A large country will turn a losing coalition into winning if the coalition just misses a member to reach the required participation or/and if the coalition has the required participation, but the participating countries are too small to have the required population. When the incomplete coalition is of the first kind, any country will do, when it is of the second, large players are generally more useful. What about small countries? If only an extra member is needed, small countries are useful, but when some population is missing, they are, generally, less interesting. The United Kingdom is one of the largest members, its departure means that the number of incomplete coalitions due to insufficient participations decreases more than of those with insufficient populations. This way smaller countries find themselves useful less often, while the change is less pronounced for large countries. In other terms, the UK is a substitute for large, but a complement for small countries. Due to the normalisation the large countries benefit, the small ones suffer. We present the power projections in Figure 2 for four regions (similar graphs for individual countries are presented in the appendix).

These four regions are affected differently by the introduction of the new, Lisbon voting rules, the demographics, and the Brexit. While the core countries may increase their influence by some $50 \%$ compared to the Nizza rules, Nordic countries including Britain and Austria have a steady increase unless,

\footnotetext{
${ }^{1}$ Its widely used alternative is the Banzhaf index. In the Banzhaf index the same players get credit for being critical, but the probability or weight of coalitions is slightly different. The results are qualitatively the same.
} 
of course, the UK exits. Southern countries are mixed - Italy balancing the decline of mid-sized members of this group - and the net result of the various effects is a relatively small variation of their total power. At last the Central and East European countries show a steady decline both individually and as a group. While these four groups had roughly equal power before the Lisbon treaty, the core countries are expected to have nearly twice the power of the CEECs by the end of the examined period. The six founding members of the EEC had about the third of the total power before Lisbon, while the same countries will have more than half in the event of a British departure.

\section{References}

Annette Kroll, D. and D. Leuffen, 2016, Ties that bind, can also strangle: the Brexit threat and the hardships of reforming the EU, Journal of European Public Policy , 1-10.

Brams, S. J. and P. J. Affuso, 1976, Power and size: A new paradox, Theory and Decision 7, 29-56.

Bräuninger, T. and T. König, 2005, Indices of Power IOP 2.0.

Buckle, R., T. Hewish, J. C. Hulsman, I. Mansfield, and R. Oulds, 2015, Directions for Britain outside the EU (Institute or Economic Affairs, London).

Dagnis Jensen, M. and H. Snaith, 2016, When politics prevails: the political economy of a Brexit, Journal of European Public Policy 1763, 1-9.

van Deemen, A. and A. Rusinowska, 2003, Paradoxes of voting power in Dutch politics, Public Choice 115, 109-137. 
European Parliament, 2015, EU budget explained: expenditure and contribution by member state. United Kingdom.

Eurostat, 2014, EUROPOP2013 - Convergence scenario, national level, Population predictions - [tps00002].

Hix, S., S. Hagemann, and D. Frantescu, 2016, Would Brexit Matter? The UK's Voting Record in the Council and the European Parliament, Tech. Rep. April, VoteWatch Europe, Brussels.

Kóczy, L. Á., 2009, Measuring Voting Power: The paradox of new members vs. the null player axiom, in: I. J. Rudas, J. Fodor, and J. Kacprzyk, eds., Towards Intelligent Engineering and Information Technology (Springer, Berlin), 67-78.

Kóczy, L. Á., 2012, Beyond Lisbon: Demographic trends and voting power in the European Union Council of Ministers, Mathematical Social Sciences 63, 158-152.

Montero, M., 2013, On the nucleolus as a power index, Homo Oeconomicus $22,551-567$.

Oliver, T., 2016, European and international views of Brexit, Journal of European Public Policy 1763, 1-8.

Rusinowska, A. and A. van Deemen, 2005, The Redistribution Paradox and the Paradox of New Members in the German Parliament, in: L. A. Petrosyan and V. V. Mazalov, eds., Game Theory and Applications (Nova, New York), 153-174.

Schmeidler, D., 1969, The Nucleolus of a Characteristic Function Game, SIAM Journal on Applied Mathematics 17, 1163-1170. 
Shapley, L. S., 1953, A Value for n-Person Games, in: H. W. Kuhn and A. Tucker, eds., Contributions to the Theory of Games, vol. II (Princeton University Press), 307-317.

Shapley, L. S. and M. Shubik, 1954, A method for evaluating the distribution of power in a committee system, American Political Science Review 48, $787-792$.

Zaporozhets, V., M. García-Valiñas, and S. Kurz, 2016, Key drivers of EU budget allocation: Does power matter?, European Journal of Political Economy 43, 57-70.

\section{A Tables}

A.1 Population predictions

A.2 Shapley-Shubik index projections for the status quo

A.3 Shapley-Shubik index projections after brexit

A.4 Adjusted projections after brexit

A.5 Graphic comparisons of Shapley-Shubik indices per country 
Table 1: Member states' population projections until 2080 (10000's) (Eurostat, 2014)

\begin{tabular}{|c|c|c|c|c|c|c|c|c|}
\hline & 2015 & 2020 & 2030 & 2040 & 2050 & 2060 & 2070 & 2080 \\
\hline European Union & 5082 & 5125 & 5185 & 5235 & 5255 & 5229 & 5201 & 5200 \\
\hline Austria & 86 & 88 & 93 & 96 & 97 & 97 & 96 & 96 \\
\hline Belgium & 113 & 118 & 129 & 139 & 148 & 154 & 160 & 166 \\
\hline Bulgaria & 72 & 70 & 65 & 61 & 58 & 55 & 52 & 49 \\
\hline Croatia & 42 & 42 & 41 & 40 & 38 & 37 & 36 & 35 \\
\hline Cyprus & 9 & 9 & 9 & 10 & 10 & 11 & 12 & 13 \\
\hline Czech Republic & 105 & 106 & 108 & 109 & 111 & 111 & 110 & 110 \\
\hline Denmark & 56 & 58 & 61 & 63 & 64 & 65 & 67 & 68 \\
\hline Estonia & 13 & 13 & 12 & 12 & 11 & 11 & 11 & 10 \\
\hline Finland & 55 & 56 & 59 & 61 & 62 & 62 & 63 & 64 \\
\hline France & 662 & 677 & 704 & 728 & 743 & 756 & 771 & 788 \\
\hline Germany & 807 & 806 & 798 & 778 & 747 & 710 & 679 & 654 \\
\hline Greece & 110 & 107 & 101 & 96 & 91 & 86 & 81 & 77 \\
\hline Hungary & 99 & 98 & 97 & 95 & 94 & 92 & 89 & 87 \\
\hline Ireland & 46 & 46 & 46 & 47 & 50 & 52 & 55 & 59 \\
\hline Italy & 609 & 620 & 641 & 662 & 671 & 663 & 655 & 651 \\
\hline Latvia & 20 & 19 & 16 & 15 & 15 & 14 & 14 & 14 \\
\hline Lithuania & 29 & 27 & 22 & 20 & 19 & 18 & 18 & 18 \\
\hline Luxembourg & 6 & 6 & 8 & 9 & 11 & 11 & 12 & 13 \\
\hline Malta & 4 & 4 & 5 & 5 & 5 & 5 & 5 & 5 \\
\hline Netherlands & 169 & 171 & 176 & 177 & 174 & 171 & 169 & 167 \\
\hline Poland & 385 & 384 & 375 & 362 & 348 & 333 & 315 & 296 \\
\hline Portugal & 104 & 101 & 98 & 94 & 89 & 82 & 76 & 71 \\
\hline Romania & 199 & 197 & 190 & 185 & 180 & 174 & 168 & 163 \\
\hline Slovakia & 54 & 54 & 53 & 51 & 49 & 46 & 42 & 39 \\
\hline Slovenia & 21 & 21 & 21 & 21 & 21 & 20 & 20 & 20 \\
\hline Spain & 464 & 458 & 445 & 446 & 455 & 461 & 465 & 476 \\
\hline Sweden & 97 & 101 & 110 & 117 & 124 & 131 & 136 & 141 \\
\hline United Kingdom & 646 & 667 & 705 & 738 & 772 & 800 & 825 & 851 \\
\hline
\end{tabular}


Table 2: Shapley-Shubik index projections for the status quo (percents)

\begin{tabular}{rrrrrrrrr} 
& 2015 & 2020 & 2030 & 2040 & 2050 & 2060 & 2070 & 2080 \\
\hline Austria & 2.02 & 2.04 & 2.10 & 2.13 & 2.14 & 2.15 & 2.15 & 2.15 \\
Belgium & 2.42 & 2.48 & 2.62 & 2.73 & 2.86 & 2.96 & 3.05 & 3.13 \\
Bulgaria & 1.82 & 1.78 & 1.70 & 1.64 & 1.60 & 1.57 & 1.54 & 1.51 \\
Croatia & 1.39 & 1.38 & 1.38 & 1.36 & 1.33 & 1.33 & 1.32 & 1.32 \\
Cyprus & 0.92 & 0.92 & 0.94 & 0.95 & 0.96 & 0.98 & 1.00 & 1.02 \\
Czech Republic & 2.30 & 2.30 & 2.31 & 2.31 & 2.33 & 2.35 & 2.34 & 2.34 \\
Denmark & 1.59 & 1.61 & 1.65 & 1.67 & 1.68 & 1.71 & 1.75 & 1.77 \\
Estonia & 0.98 & 0.98 & 0.98 & 0.98 & 0.97 & 0.98 & 0.99 & 0.99 \\
Finland & 1.57 & 1.58 & 1.62 & 1.64 & 1.66 & 1.67 & 1.70 & 1.71 \\
France & 11.27 & 11.45 & 11.78 & 12.13 & 12.35 & 12.65 & 12.98 & 13.26 \\
Germany & 14.43 & 14.23 & 13.76 & 13.15 & 12.43 & 11.74 & 11.14 & 10.61 \\
Greece & 2.37 & 2.31 & 2.21 & 2.13 & 2.06 & 2.00 & 1.94 & 1.89 \\
Hungary & 2.21 & 2.18 & 2.15 & 2.11 & 2.10 & 2.08 & 2.05 & 2.03 \\
Ireland & 1.44 & 1.44 & 1.44 & 1.45 & 1.49 & 1.53 & 1.58 & 1.65 \\
Italy & 10.24 & 10.35 & 10.59 & 10.88 & 10.97 & 10.85 & 10.69 & 10.55 \\
Latvia & 1.08 & 1.06 & 1.03 & 1.02 & 1.03 & 1.02 & 1.03 & 1.04 \\
Lithuania & 1.20 & 1.17 & 1.11 & 1.09 & 1.08 & 1.07 & 1.08 & 1.09 \\
Luxembourg & 0.88 & 0.88 & 0.92 & 0.94 & 0.97 & 0.98 & 1.00 & 1.02 \\
Malta & 0.85 & 0.85 & 0.88 & 0.89 & 0.90 & 0.90 & 0.91 & 0.92 \\
Netherlands & 3.27 & 3.28 & 3.31 & 3.29 & 3.24 & 3.20 & 3.18 & 3.14 \\
Poland & 6.43 & 6.33 & 6.07 & 5.79 & 5.58 & 5.39 & 5.15 & 4.89 \\
Portugal & 2.28 & 2.22 & 2.17 & 2.10 & 2.03 & 1.94 & 1.87 & 1.81 \\
Romania & 3.74 & 3.69 & 3.53 & 3.42 & 3.33 & 3.25 & 3.16 & 3.09 \\
Slovakia & 1.56 & 1.55 & 1.54 & 1.51 & 1.48 & 1.45 & 1.41 & 1.37 \\
Slovenia & 1.09 & 1.09 & 1.10 & 1.10 & 1.11 & 1.10 & 1.11 & 1.12 \\
Spain & 7.56 & 7.37 & 6.98 & 6.85 & 6.88 & 6.97 & 7.00 & 7.13 \\
Sweden & 2.18 & 2.22 & 2.34 & 2.42 & 2.51 & 2.63 & 2.70 & 2.78 \\
United Kingdom & 10.95 & 11.25 & 11.80 & 12.33 & 12.94 & 13.59 & 14.15 & 14.66 \\
\hline & & & & & & & &
\end{tabular}


Table 3: Shapley-Shubik index projections after brexit (percents)

\begin{tabular}{rrrrrrrrr} 
& 2015 & 2020 & 2030 & 2040 & 2050 & 2060 & 2070 & 2080 \\
\hline Austria & 2.16 & 2.18 & 2.24 & 2.27 & 2.29 & 2.31 & 2.31 & 2.32 \\
Belgium & 2.59 & 2.66 & 2.82 & 2.96 & 3.09 & 3.21 & 3.32 & 3.41 \\
Bulgaria & 1.91 & 1.87 & 1.79 & 1.71 & 1.66 & 1.62 & 1.59 & 1.54 \\
Croatia & 1.42 & 1.42 & 1.41 & 1.38 & 1.35 & 1.34 & 1.34 & 1.32 \\
Cyprus & 0.88 & 0.89 & 0.90 & 0.91 & 0.91 & 0.93 & 0.95 & 0.97 \\
Czech Republic & 2.46 & 2.46 & 2.48 & 2.48 & 2.51 & 2.52 & 2.54 & 2.53 \\
Denmark & 1.65 & 1.68 & 1.73 & 1.74 & 1.76 & 1.78 & 1.83 & 1.85 \\
Estonia & 0.95 & 0.95 & 0.94 & 0.94 & 0.93 & 0.93 & 0.93 & 0.93 \\
Finland & 1.63 & 1.64 & 1.69 & 1.71 & 1.73 & 1.73 & 1.76 & 1.78 \\
France & 13.41 & 13.68 & 14.21 & 14.77 & 15.28 & 15.94 & 16.58 & 17.19 \\
Germany & 17.42 & 17.23 & 16.77 & 16.14 & 15.38 & 14.67 & 14.05 & 13.53 \\
Greece & 2.54 & 2.48 & 2.37 & 2.27 & 2.20 & 2.13 & 2.06 & 2.00 \\
Hungary & 2.36 & 2.34 & 2.30 & 2.26 & 2.24 & 2.22 & 2.19 & 2.18 \\
Ireland & 1.49 & 1.48 & 1.49 & 1.49 & 1.54 & 1.57 & 1.64 & 1.70 \\
Italy & 12.12 & 12.31 & 12.68 & 13.15 & 13.47 & 13.50 & 13.46 & 13.46 \\
Latvia & 1.06 & 1.05 & 1.01 & 0.99 & 0.99 & 0.97 & 0.98 & 0.99 \\
Lithuania & 1.21 & 1.18 & 1.10 & 1.07 & 1.05 & 1.03 & 1.04 & 1.06 \\
Luxembourg & 0.84 & 0.84 & 0.88 & 0.89 & 0.93 & 0.93 & 0.95 & 0.97 \\
Malta & 0.81 & 0.81 & 0.83 & 0.83 & 0.83 & 0.83 & 0.84 & 0.85 \\
Netherlands & 3.51 & 3.53 & 3.57 & 3.55 & 3.51 & 3.48 & 3.46 & 3.42 \\
Poland & 7.11 & 7.08 & 6.90 & 6.64 & 6.34 & 6.13 & 5.82 & 5.45 \\
Portugal & 2.44 & 2.39 & 2.32 & 2.24 & 2.16 & 2.06 & 1.98 & 1.90 \\
Romania & 4.01 & 3.94 & 3.79 & 3.68 & 3.60 & 3.52 & 3.45 & 3.36 \\
Slovakia & 1.61 & 1.61 & 1.60 & 1.56 & 1.52 & 1.48 & 1.43 & 1.38 \\
Slovenia & 1.08 & 1.08 & 1.09 & 1.09 & 1.08 & 1.07 & 1.08 & 1.09 \\
Spain & 9.00 & 8.86 & 8.58 & 8.67 & 8.94 & 9.26 & 9.49 & 9.81 \\
Sweden & 2.33 & 2.39 & 2.51 & 2.60 & 2.71 & 2.85 & 2.95 & 3.01 \\
\hline & & & & & & & &
\end{tabular}


Table 4: Adjusted Shapley-Shubik index projections after brexit (percents)

\begin{tabular}{rrrrrrrrr} 
& 2015 & 2020 & 2030 & 2040 & 2050 & 2060 & 2070 & 2080 \\
\hline Austria & 2.08 & 2.10 & 2.17 & 2.20 & 2.22 & 2.23 & 2.23 & 2.24 \\
Belgium & 2.50 & 2.57 & 2.73 & 2.86 & 2.99 & 3.10 & 3.21 & 3.29 \\
Bulgaria & 1.85 & 1.81 & 1.73 & 1.66 & 1.61 & 1.57 & 1.54 & 1.49 \\
Croatia & 1.38 & 1.37 & 1.36 & 1.33 & 1.30 & 1.29 & 1.29 & 1.28 \\
Cyprus & 0.85 & 0.86 & 0.87 & 0.88 & 0.88 & 0.89 & 0.92 & 0.94 \\
Czech Republic & 2.38 & 2.38 & 2.39 & 2.39 & 2.43 & 2.44 & 2.45 & 2.45 \\
Denmark & 1.59 & 1.62 & 1.67 & 1.68 & 1.70 & 1.72 & 1.77 & 1.79 \\
Estonia & 0.92 & 0.92 & 0.91 & 0.91 & 0.90 & 0.89 & 0.90 & 0.89 \\
Finland & 1.58 & 1.59 & 1.64 & 1.66 & 1.67 & 1.67 & 1.70 & 1.72 \\
France & 12.95 & 13.22 & 13.72 & 14.27 & 14.76 & 15.40 & 16.02 & 16.61 \\
Germany & 16.83 & 16.65 & 16.21 & 15.59 & 14.86 & 14.17 & 13.57 & 13.07 \\
Greece & 2.46 & 2.40 & 2.29 & 2.20 & 2.12 & 2.06 & 1.99 & 1.93 \\
Hungary & 2.28 & 2.26 & 2.23 & 2.18 & 2.17 & 2.15 & 2.12 & 2.10 \\
Ireland & 1.44 & 1.43 & 1.44 & 1.44 & 1.49 & 1.52 & 1.58 & 1.64 \\
Italy & 11.71 & 11.89 & 12.25 & 12.70 & 13.01 & 13.04 & 13.00 & 13.00 \\
Latvia & 1.03 & 1.01 & 0.97 & 0.96 & 0.96 & 0.94 & 0.95 & 0.96 \\
Lithuania & 1.17 & 1.14 & 1.07 & 1.03 & 1.01 & 1.00 & 1.01 & 1.02 \\
Luxembourg & 0.81 & 0.81 & 0.85 & 0.86 & 0.90 & 0.89 & 0.92 & 0.94 \\
Malta & 0.78 & 0.78 & 0.81 & 0.80 & 0.80 & 0.80 & 0.81 & 0.82 \\
Netherlands & 3.39 & 3.41 & 3.45 & 3.43 & 3.39 & 3.36 & 3.34 & 3.31 \\
Poland & 6.87 & 6.84 & 6.67 & 6.41 & 6.12 & 5.92 & 5.62 & 5.27 \\
Portugal & 2.36 & 2.30 & 2.24 & 2.17 & 2.09 & 1.99 & 1.91 & 1.83 \\
Romania & 3.87 & 3.81 & 3.66 & 3.55 & 3.48 & 3.40 & 3.33 & 3.24 \\
Slovakia & 1.56 & 1.55 & 1.55 & 1.50 & 1.47 & 1.43 & 1.38 & 1.34 \\
Slovenia & 1.04 & 1.04 & 1.05 & 1.05 & 1.05 & 1.03 & 1.04 & 1.05 \\
Spain & 8.69 & 8.56 & 8.29 & 8.37 & 8.63 & 8.94 & 9.16 & 9.48 \\
Sweden & 2.25 & 2.30 & 2.42 & 2.52 & 2.62 & 2.76 & 2.85 & 2.91
\end{tabular}



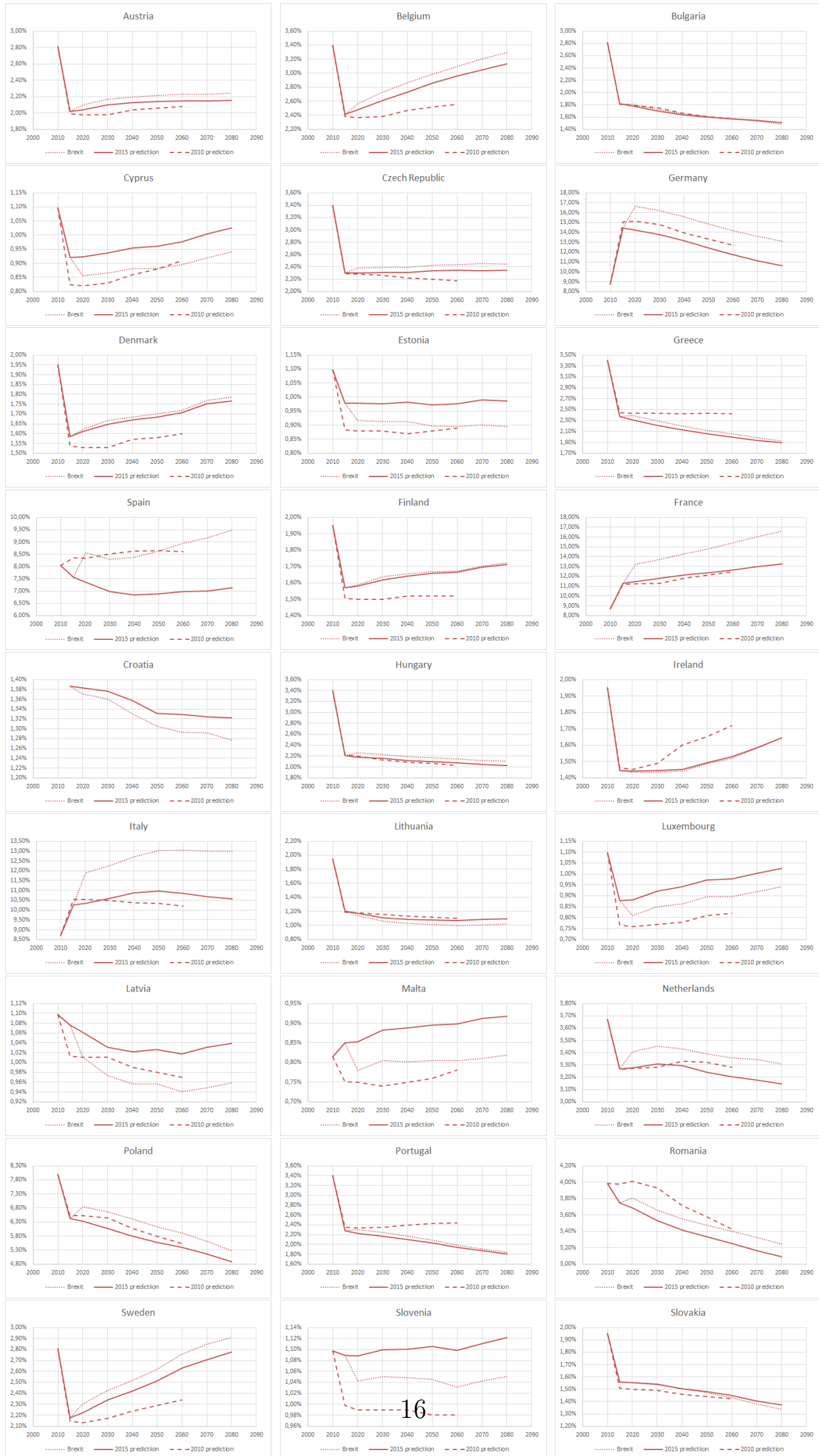

Figure 3: Shapley-Shubik index forecasts per country. Dashed / solid / dotted lines respectively show 2010 (Kóczy, 2012), current, and Brexit forecasts 